\section{Prevalence of comorbidities between mood and anxiety disorders: associated factors in a population sample of young adults in southern Brazil}

\author{
Prevalência de comorbidades entre transtornos de \\ humor e ansiedade: fatores associados em uma \\ amostra populacional de adultos jovens no \\ Sul do Brasil
}

Prevalencia de la comorbilidad entre el estado de ánimo y los trastornos de ansiedad: factores asociados en una muestra de población de adultos jóvenes en el sur de Brasil

\begin{abstract}
This research aims to evaluate factors associated with the presence of comorbidities between mood and anxiety disorders in young adults aged 18 to 24 years, from Pelotas, Rio Grande do Sul State, Brazil. This was a cross-sectional, population-based study with a probabilistic sample by conglomerates. The Mini International Neuropsychiatric Interview (MINI) was used to as sess mood and anxiety disorders. The prevalence of mental disorders in the sample $(n=1,561)$ was of $26.8 \%$ of which $9.7 \%$ had comorbidities between mood and anxiety disorders. The prevalence of comorbidities on mood and anxiety disorders is almost three times higher among women than men $(p<0.001)$. Lower education levels, socioeconomic status $(p<0.001)$ and a history of divorced parents $(p<0.050)$ was associated with comorbidities between mood and anxiety disorders. The main conclusion is that social factors are highly associated with comorbidities between mood and anxiety disorders. Prevention strategies on mental health should focus particularly on women in vulnerable social conditions.
\end{abstract}

Mental Disorders; Mental Health; Young Adult
Mariane Ricardo Acosta Lopez Molina 1

Bárbara Spessato 1

Karen Jansen 1

Ricardo Pinheiro 1

Ricardo Silva 1

Luciano Dias de Mattos Souza ${ }^{1}$

\section{Resumo}

Esta investigação teve como objetivo avaliar a presença de comorbidades entre transtornos de humor e ansiedade, assim como seus fatores associados, em adultos jovens entre 18 e 24 anos de idade em Pelotas, Rio Grande do Sul, Brasil. Em estudo transversal de base populacional a seleção amostral foi feita por conglomerados. $O$ Mini International Neuropsychiatric Interview (MINI) foi utilizado para avaliar os transtornos de humor e ansiedade. A prevalência de transtornos mentais na amostra estudada ( $n=$ 1.561) foi de 26,8\%, dos quais 9,7\% apresentaram comorbidade entre transtornos de humore ansiedade. A comorbidade entre transtornos de humor e ansiedade foi quase três vezes maior entre as mulheres quando comparadas aos homens ( $p<0,001)$. Níveis mais baixos de escolaridade, nível socioeconômico $(p<0,001)$ e histórico de pais divorciados $(p<0,050)$ apresentaram-se associados com comorbidade entre transtornos de humor e ansiedade. A principal conclusão é que os fatores sociais são altamente associados com comorbidade entre transtornos de humor e ansiedade.

Transtornos Mentais; Saúde Mental; Adulto Jovem 


\section{Introduction}

Epidemiological studies show that millions of people in the world suffer from a mental disorder, especially in developing countries 1,2,3. Comorbidity cases are also very common in population studies with prevalence ranging from $14-23 \% 4,5$ with significant consequences for mental health. Comorbid mood and anxiety disorders (54.3\%) 6 and pure cases have a high prevalence in the population (9.5 and $18.1 \%)^{5}$ resulting in significant damage to the quality of life. Studies have shown that comorbidity, especially between mood and anxiety disorders, is associated with increased severity, higher duration of illness, greater functioning impairment, and more frequent use of health services $7,8,9,10$. Understanding the social factors related to comorbidity cases, especially in a highly prevalent diagnostic family of mental disorders, such as mood and anxiety disorders, may have important implications for the development of public health policies.

Studies on cross family diagnostic comorbidity of mood and anxiety disorders associated with social factors are scarce, especially among young adults. The few studies that assess young adults do not focus on the ages of 18 to 24 , the most frequent onset period of those mental disorders 5,11. Nonetheless, some sociodemographic factors have been previously associated with the presence of comorbid mental disorder such as female gender 6; low levels of education 6 ; and unmarried status 12 . It is important to highlight that comorbidity was not presented in those studies, so it is still unclear if those social factors will relate similarly to the comorbidity of mood and anxiety disorders.

It is noteworthy that most studies of psychopathology tend to focus on single-disorder cases and even in clinical trials comorbidity cases are not identified. It is understandable that pure cases are more often studied since it minimizes the effect of possible confounders. In fact, we often approach comorbid cases based on evidence derived from studies of single disorder cases. It is important to understand the specific characteristics of cross diagnostic family comorbidity particularly considering that the prevalence of some comorbid cases is at least equal to single disorders in the population 5 . In addition, Lamers et al. 13 found that in $57 \%$ of comorbid cases, anxiety was preceded by depression; in 18\% of cases, depression preceded anxiety. This reinforces the rationale of investigating not only pure cases but also the relationship between comorbidities, its impact on health, and the associated risk factors in a young adult population 13 .

Therefore, an assessment of the distribution of different mental disorders is necessary to allow for a better understanding of such psychiatric phenomena and to contribute to the development of preventive interventions in mental health, especially among young adults. Because of the scarcity of research involving this theme in the scientific literature, the present study aims to evaluate factors associated with the presence of comorbidities between mood and anxiety disorders in young adults aged 18 to 24, from Pelotas, Rio Grande do Sul State, Brazil.

\section{Methods}

This is a cross-sectional, population-based study with young adults, aged between 18 to 24 years, living in the urban area of Pelotas, a city in southern Brazil, with approximately 330,000 inhabitants (83\% of whom live in urban areas).

The sample selection was performed by clusters considering the population of 39,667 individuals in the above age range according to the current census of 448 sectors in the city (http://www.ibge. gov.br, accessed on Jun/2012). To assure the necessary sample size, 89 census-based sectors were randomly selected. The home selection in the sectors was performed using systematic sampling The first home was considered to be the house at the corner as pre-established by the IBGE (Brazilian Institute of Geographic and Statistics) as the beginning of the sector. Given the required number of respondents and to increase representativeness, the interval of selection was determined by skipping two houses. After identifying the subjects, we explained the aims of the study and in case of agreement to participate we scheduled a home visit to conduct the interview. Psychology majors with extensive training in conducting interviews collected the data. We identified 1,762 young adults who met the criteria for inclusion; 201 (11.4\%) were not found at home during three home visits or refused to complete the interview and were excluded from the total sample. Thus, a total of 1,561 respondents were analyzed.

Considering measured prevalence of comorbidity between mood and anxiety disorders (9.7\%) found in the present study, a sample size estimation of 1,132 young adults was needed with a $95 \%$ confidence level and the lowest error accepted was $1.7 \%$. So the sample was larger than what was required for our purpose. At first, participants answered a questionnaire consisting of sociodemographic questions (e.g. education, employment) and general health issues. A socioeconomic evaluation of the participants was performed using the classification from the Brazilian Association of Research Companies (http://www.ibge.gov. br, accessed on 10/Mar/2010), which is based on 
the total of material goods and the householder's education. This scale provides a list of consumer items and the respondent is asked to identify how many of them exist in their home. Moreover, the level of education of the household head is also considered in the total score that indicates the classification of socioeconomic classes (A, B, C, $\mathrm{D}, \mathrm{E})$; "A" refers to the highest socioeconomic class and "E" to the lowest.

Current mental disorders were assessed using the Mini International Neuropsychiatric Interview 5.0 (MINI). This short interview (15 to 30 minutes) is designed for use in clinical practice and aimed at diagnosing the interviewees according to the Diagnostic and Statistical Manual of Mental Disorders, 4th edition (DSM-IV) and the International Statistical Classification of Diseases and Related Health Problems, 10th revision (ICD-10), criteria. Although, the psychometric characteristics for each disorder assessed varies compared to a Structured Clinical Interview from DSM (SCID), the psychometric characteristics of MINI are considered appropriate 14 . We assessed the following modules of current disorders of MINI: major depressive episode, dysthymia, hypomania and mania episodes, panic disorder, agoraphobia, social phobia, obsessive-compulsive disorder, post-traumatic stress disorder, generalized anxiety disorder. The main dependent nominal variable in the study was categorized into subjects with no psychiatric disorders, with mood disorder, with anxiety disorder and those with comorbidity between mood and anxiety disorders. We focused on cross family diagnostic comorbidity, so to be considered a comorbidity case the participants had to present full diagnostic criteria for at least one disorder in each diagnostic family (mood and anxiety disorders).

Data entry and processing was carried out through double data entry on Epi-Info 6.04d (Centers for Disease Control and Prevention, Atlanta, U.S.A.) software. The software checked data entry automatically and also tested for inconsistencies on double data entry. For the statistical analysis, we used SPSS, version 13 (SPSS Inc., Chicago, U.S.A.). Descriptive statistics were used to characterize the study sample and to present the prevalence of comorbidity of mental disorders.

The first analytic approach to select the variables was a crude multinomial regression describing associations between the occurrence of mental disorders and the independent variables investigated. Finally, adjusted multinomial regression was used following a hierarchical framework approach ${ }^{15}$. Those with a $p$-value $\leq 0.2$ in the bivariate tests were included in the model.

Young adults who presented with any psychiatric disorder and/or drug abuse were directed to psychiatric outpatient care. The project was approved by the Ethics Research Committee of Pelotas Catholic University according to process number 2009/24.

\section{Results}

As presented in Table 1, most of the sample was female $(56.4 \%)$, white $(73.5 \%)$, had 9 to 11 years of education, belonged to economic class C (48.1\%), lived with a father and/or mother (65.8\%), had parents who were not divorced (64\%), was not living with a partner (28.2\%), worked in the past 12 months $(66.9 \%)$, and was religious $(62 \%)$.

The results of the MINI interviews showed that 9.7\% had comorbidity between mood and anxiety disorders and $26.8 \%$ of the sample had at least one of the conditions assessed (Figure 1). In addition, the prevalence of pure mood disorder was $5.9 \%$, and $11.1 \%$ of pure anxiety disorder. The three most prevalent diagnoses were major depressive disorder (12.6\%), agoraphobia (12.3\%) and generalized anxiety disorder (9.7\%) (Table 2).

Comorbidities between mood and anxiety disorders were more frequently observed among females; and among participants that did not work in the past 12 months, with low socioeconomic status, fewer years of education, and divorced parents. Skin color also showed a difference in the proportion of comorbidities between mood and anxiety disorders but with no statistical significance (Table 3 ). In regard to mood disorders, a statistically significant higher proportion was observed in females, unemployed people and people not living with a partner. Similarly, female gender and unemployment were related to a higher prevalence of anxiety disorders.

After the adjusted analysis, comorbidities between mood and anxiety disorders were three times higher for women than men, and inversely associated with education and socioeconomic status. Young adults without divorced parents showed $31 \%$ lower odds of presenting comorbidities than people with divorced parents (Table 4). The analysis that considered the odds ratios for mood disorders alone showed a higher prevalence among females and people who were not living with a partner. The female gender was the only independent variable correlated with anxiety disorders.

\section{Discussion}

The prevalence of mental disorders in this study was high $(26.8 \%)$ as well as comorbidity rates between anxiety and mood disorders (9.7\%). Other 
Table 1

Sample characteristics of young adults aged 18 to 24 from the city of Pelotas, southern Brazil, 2007-2008 $(n=1,561)$.

\begin{tabular}{|c|c|c|}
\hline Variable & $\mathrm{n}$ & $\%$ * \\
\hline \multicolumn{3}{|l|}{ Sex } \\
\hline Male & 681 & 43.6 \\
\hline Female & 880 & 56.4 \\
\hline \multicolumn{3}{|l|}{ Color ** } \\
\hline White & 1,144 & 73.5 \\
\hline Black & 237 & 15.2 \\
\hline Mulatto & 146 & 9.4 \\
\hline Yellow & 13 & 0.8 \\
\hline Indian & 17 & 1.1 \\
\hline \multicolumn{3}{|c|}{ Schooling (in years) ${ }^{\star \star \star}$} \\
\hline $0-4$ & 115 & 7.4 \\
\hline $5-8$ & 345 & 22.2 \\
\hline $9-11$ & 630 & 40.5 \\
\hline 12 or more & 465 & 29.9 \\
\hline \multicolumn{3}{|c|}{ Socioeconomic class \# } \\
\hline$A+B$ & 583 & 37.4 \\
\hline$C$ & 751 & 48.1 \\
\hline$D+E$ & 226 & 14.5 \\
\hline \multicolumn{3}{|c|}{ Living with father and/or mother \# } \\
\hline No & 533 & 34.2 \\
\hline Yes & 1,027 & 65.8 \\
\hline \multicolumn{3}{|c|}{ Divorced parents \#\# } \\
\hline No & 994 & 64.0 \\
\hline Yes & 560 & 36.0 \\
\hline \multicolumn{3}{|c|}{ Living with a partner \#\#\# } \\
\hline No & 1,120 & 71.8 \\
\hline Yes & 439 & 28.2 \\
\hline \multicolumn{3}{|c|}{ Work in the past 12 months $\S$} \\
\hline No & 510 & 33.1 \\
\hline Yes & 1,031 & 66.9 \\
\hline \multicolumn{3}{|l|}{ Any religion \# } \\
\hline No & 593 & 38.0 \\
\hline Yes & 967 & 62.0 \\
\hline
\end{tabular}

* All proportions refer to valid percentages;

** Missing value from 4 cases;

*** Missing value from 6 cases;

\# Missing value from 1 case;

\#\# Missing value from 7 cases;

\#\#\# Missing value from 2 cases;

$\S$ Missing value from 20 cases.

studies also demonstrate a high prevalence of mental disorders among young adults, but most studies did not report cross diagnostic family comorbidity rates. Also, comparisons among studies are relatively limited due to the use of different assessment tools. The assessment of mental disorders in the present study was performed using
MINI, an instrument with adequate psychometric properties while other studies used screening questionnaires. Mini has the advantage of being a reliable, structured diagnostic interview based on the diagnostic criteria of ICD-10 and DSM-IV, with easy and fast applicability compared to other standard clinical interviews. 
Venn diagram with distribution of mental disorders among young adults from the city of Pelotas, southern Brazil, 2007-2008 ( $n=1,561)$.

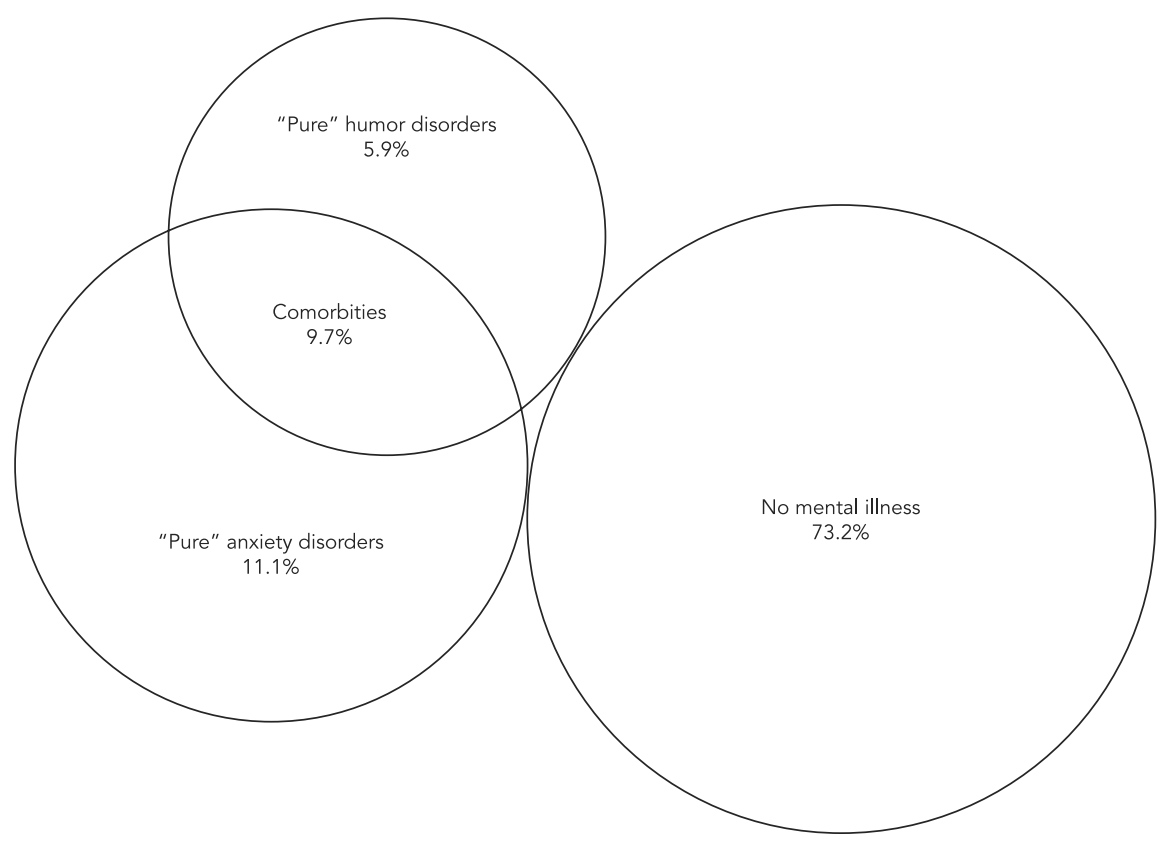

Population based studies assessing the prevalence of comorbidity of psychiatric disorders are scarce. The few studies that assesses psychiatric disorders do so using a single diagnostic family (e.g. Mood disorders) or individually (e.g. Major depression), focusing only on the most common mental disorders (e.g. Nonpsychotic depression, anxiety and somatoform symptoms) 16,17. It is important to highlight that, in the present study specific, social factors were related only to cross family diagnostic comorbidity, and not to the pure cases of anxiety or mood disorders.

The data suggests that anxiety and mood disorders not only have high prevalences, but also show high comorbidity rates. In fact, comorbidity rates were higher than the prevalence of pure mood disorder cases in the present study. Some studies also demonstrate that comorbidity cases can be more prevalent than pure mood or anxiety disorders 6,12 . Similar results have also been found in early stages of adolescence and young adult life 18,19. We believe that the high prevalence of comorbid anxiety and depressive disorder might be explained by the similarity of symptoms and specific social vulnerability factors for comorbidities.
It is important to highlight that socioeconomic status and education were inversely associated only with psychiatric comorbidity between mood and anxiety disorder. In regard to education, similarly to the De Graaf et al. 6 study, we found that participants with fewer years of education showed higher rates of comorbidities between mood and anxiety disorders. The present study highlights a possible influence of education and socioeconomic status in more complex and severe cases, as the comorbidity between mood and anxiety disorders.

Interestingly, we found that having divorced parents was related only to the presence of comorbidity cases in young adults. Studies show that divorced parents convey less social support in different periods of life 20. This relationship is frequently reported in children with divorced parents, possibly as a result of the traumatic experience of the parents' separation in childhood. Experiencing trauma is a risk factor to the onset of comorbidities between depressive and anxiety disorders ${ }^{6}$. In adolescence, parental divorce was related to low social support from the family and high levels of depression/anxiety 20. In fact, not living with parents in adolescence is related 
Table 2

Prevalence of mental disorders, according to the Mini International Neuropsychiatric Interview (MINI) in young adults aged 18 to 24 in the city of Pelotas, Rio Grande do Sul, Brazil, 2007-2008. $(n=1,561)$

\begin{tabular}{|c|c|c|}
\hline Type of disorder & $\mathrm{n}$ & $\%$ \\
\hline \multicolumn{3}{|c|}{ Comorbidity between mood and anxiety disorder } \\
\hline No & 1,409 & 90.3 \\
\hline Yes & 152 & 9.7 \\
\hline \multicolumn{3}{|l|}{ Mood disorder } \\
\hline No & 1,317 & 84.4 \\
\hline Yes & 244 & 15.6 \\
\hline \multicolumn{3}{|c|}{ Major depressive disorder } \\
\hline No & 1,365 & 87.4 \\
\hline Yes & 196 & 12.6 \\
\hline \multicolumn{3}{|l|}{ Dysthymia } \\
\hline No & 1,519 & 97.3 \\
\hline Yes & 42 & 2.7 \\
\hline \multicolumn{3}{|l|}{ Manic episode } \\
\hline No & 1,444 & 92.5 \\
\hline Yes & 117 & 7.5 \\
\hline \multicolumn{3}{|l|}{ Hypomanic disorder } \\
\hline No & 1,478 & 94.7 \\
\hline Yes & 83 & 5.3 \\
\hline \multicolumn{3}{|l|}{ Anxiety disorders } \\
\hline No & 1,235 & 79.1 \\
\hline Yes & 326 & 20.9 \\
\hline \multicolumn{3}{|c|}{ Generalized anxiety disorder } \\
\hline No & 1,409 & 90.3 \\
\hline Yes & 152 & 9.7 \\
\hline \multicolumn{3}{|l|}{ Social phobia } \\
\hline No & 1,498 & 96.0 \\
\hline Yes & 63 & 4.0 \\
\hline \multicolumn{3}{|l|}{ Panic disorder } \\
\hline No & 1,522 & 97.5 \\
\hline Yes & 39 & 2.5 \\
\hline \multicolumn{3}{|l|}{ Agoraphobia } \\
\hline No & 1,369 & 87.7 \\
\hline Yes & 192 & 12.3 \\
\hline \multicolumn{3}{|c|}{ Obsessive compulsive disorder } \\
\hline No & 1,510 & 96.7 \\
\hline Yes & 51 & 3.3 \\
\hline \multicolumn{3}{|c|}{ Post traumatic stress disorder } \\
\hline No & 1,529 & 98.0 \\
\hline Yes & 32 & 2.0 \\
\hline
\end{tabular}

to higher levels of depression and anxiety ${ }^{11}$. Accordingly, young adults with divorced parents might experience less social support during their lifetime.

Contrary to the literature, we did not find a higher prevalence of comorbid cases or pure anxi- ety disorder among people who do not live with a partner. We only found this relationship among pure cases of mood disorder. According to Meng \& D'Arcy ${ }^{12}$, unmarried young adults were more likely to develop anxiety or mood disorders with comorbidity with other mental conditions. In an- 


\section{Table 3}

Bivariate analysis between independent variables in study and presence of mood and anxiety disorders and its comorbidity in young adults aged 18 to 24 in the city of Pelotas, Rio Grande do Sul, Brazil, 2007-2008 ( $n=1.561$ )

\begin{tabular}{|c|c|c|}
\hline \multirow[t]{2}{*}{ Variable } & \multicolumn{2}{|c|}{ Comorbidity between mood and anxiety disorders * } \\
\hline & PR & $95 \% \mathrm{Cl}$ \\
\hline \multicolumn{3}{|l|}{ Sex ** } \\
\hline Male & 1.00 & \\
\hline Female & 2.54 & $1.74-3.70$ \\
\hline \multicolumn{3}{|l|}{ 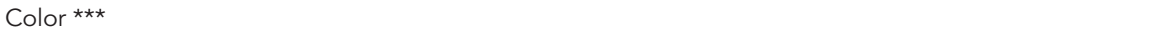 } \\
\hline White & 1.00 & \\
\hline Non white & 0.70 & $0.48-1.00$ \\
\hline \multicolumn{3}{|c|}{ Schooling (years) ** } \\
\hline $0-4$ & 4.09 & $2.25-7.45$ \\
\hline $5-8$ & 2.54 & $1.55-4.17$ \\
\hline $9-11$ & 1.49 & $0.93-2.41$ \\
\hline 12 or more & 1.00 & \\
\hline \multicolumn{3}{|c|}{ Socioeconomic class ** } \\
\hline$A+B$ & 0.32 & $0.20-0.52$ \\
\hline C & 0.55 & $0.36-0.84$ \\
\hline $\mathrm{D}+\mathrm{E}$ & 1.00 & \\
\hline \multicolumn{3}{|c|}{ Work in the past 12 months } \\
\hline No & 1.11 & $0.77-1.59$ \\
\hline Yes & 1.00 & \\
\hline \multicolumn{3}{|c|}{ Divorced parents ** } \\
\hline No & 0.60 & $0.43-0.85$ \\
\hline Yes & 1.00 & \\
\hline \multicolumn{3}{|c|}{ 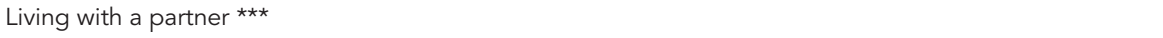 } \\
\hline No & 0.73 & $0.51-1.05$ \\
\hline Yes & 1.00 & \\
\hline \multicolumn{3}{|l|}{ Any religion *** } \\
\hline No & 0.92 & $0.64-1.31$ \\
\hline Yes & 1.00 & \\
\hline
\end{tabular}

95\% Cl: 95\% confidence interval; PR: prevalence ratio.

* Analysis conducted with valid percentages;

** $\mathrm{p}<0.001$;

${ }^{\star \star \star} p>0.05$; color $p=0.05$, living with a partner $p=0.09$, and any religion $p=0.64$.

other study, people who do not live with a partner show a higher prevalence of comorbidity between mood and anxiety disorder 6 . It is still unclear why we did not find this relationship among comorbid cases, and pure anxiety disorder. We speculate it might be due to the younger age of our sample compared to other studies.

In regard to gender, women not only more frequently presented comorbidity between mood and anxiety disorder, but also pure cases of both disorders compared to men. In fact, similar to other studies 11,19 , we found that women are affected three times more often than men. It is noteworthy that women are more often affected by mental disorders than men in comorbidity cases 21 . Additionally women present twice the rate of comorbidity between mood and anxiety disorders than men ${ }^{6}$. This finding may be explained by the fact that women have worse self-rated health; therefore, women may be more willing than men to express their symptoms 22,23. Another trait is that women are more likely to remember and report their mood swings than men 24 .

Among the limitations of this study is the cross-sectional study design that precludes the evaluation of any causal relationship between the independent variables and the number of mental disorders. A potential source of bias is that inter- 
Table 4

Multinominal regression for presence of mood and anxiety disorders and its comorbidity in youth aged 18 to 24 in the city of Pelotas, Rio Grande do Sul, Brazil, 2007-2008 $(n=1,561)$

\begin{tabular}{|c|c|c|c|c|c|c|}
\hline \multirow[t]{2}{*}{ Variable } & \multicolumn{2}{|c|}{$\begin{array}{c}\text { Comorbidity between mood and } \\
\text { anxiety disorders * }\end{array}$} & \multicolumn{2}{|c|}{ "Pure"anxiety disorder * } & \multicolumn{2}{|c|}{ "Pure" mood disorder * } \\
\hline & PR & $95 \% \mathrm{Cl}$ & PR & $95 \% \mathrm{Cl}$ & PR & $95 \% \mathrm{Cl}$ \\
\hline \multicolumn{7}{|l|}{ 1st level } \\
\hline \multicolumn{7}{|l|}{ Sex } \\
\hline Male & 1.00 & & 1.00 & & 1.00 & \\
\hline Female & $2.84 * \star$ & $1.92-4.19$ & $1.88^{* \star}$ & $1.33-2.64$ & $2.15 * \star$ & $1.35-3.42$ \\
\hline \multicolumn{7}{|l|}{ Color } \\
\hline Non white & 1.00 & & 1.00 & & 1.00 & \\
\hline White & 0.86 & $0.58-1.27$ & 0.84 & $0.57-1.22$ & 0.63 & $0.39-1.01$ \\
\hline \multicolumn{7}{|c|}{ Schooling (years) } \\
\hline $0-4$ & $3.87 * \star$ & $2.00-7.49$ & 0.54 & $0.21-1.35$ & $2.55 * *$ & $1.06-6.12$ \\
\hline $5-8$ & $2.13 * \star$ & $1.22-3.72$ & 1.08 & $0.65-1.79$ & 1.34 & $0.65-2.77$ \\
\hline $9-11$ & 1.31 & $0.79-2.17$ & 1.05 & $0.70-1.58$ & 1.63 & $0.92-2.88$ \\
\hline 12 or more & 1.00 & & 1.00 & & 1.00 & \\
\hline \multicolumn{7}{|c|}{ Socioeconomic class } \\
\hline$A+B$ & 0.57 & $0.32-1.00$ & 0.77 & $0.45-1.33$ & 1.70 & $0.76-3.80$ \\
\hline C & 0.55 & $0.44-1.09$ & 0.70 & $0.43-1.14$ & 1.44 & $0.69-2.99$ \\
\hline$D+E$ & 1.00 & & 1.00 & & 1.00 & \\
\hline \multicolumn{7}{|l|}{ 2nd level } \\
\hline \multicolumn{7}{|c|}{ Work in the past 12 months } \\
\hline No & 0.89 & $0.61-1.30$ & 1.06 & $0.75-1.51$ & 1.10 & $0.70-1.76$ \\
\hline Yes & 1.00 & & 1.00 & & 1.00 & \\
\hline \multicolumn{7}{|c|}{ Divorced parents } \\
\hline No & 0.70 & $0.49-0.99$ & 0.99 & $0.70-1.41$ & 0.75 & $0.48-1.19$ \\
\hline Yes & 1.00 & & 1.00 & & 1.00 & \\
\hline \multicolumn{7}{|c|}{ Living with a partner } \\
\hline No & 1.16 & $0.78-1.74$ & 1.13 & $0.76-1.69$ & 2.88 ** & $1.55-5.37$ \\
\hline Yes & 1.00 & & 1.00 & & 1.00 & \\
\hline \multicolumn{7}{|l|}{ Any religion } \\
\hline No & 1.26 & $0.87-1.81$ & 1.39 & $0.98-1.98$ & 0.81 & $0.51-1.29$ \\
\hline Yes & 1.00 & & 1.00 & & 1.00 & \\
\hline
\end{tabular}

95\% Cl: 95\% confidence interval; PR: prevalence ratio.

* Analysis conducted with valid percentages;

** $p<0.050$.

views rely on self-reporting and were conducted during home visits which may lead to an unwillingness to participate and non-disclosure, for example, about the risky behaviors common in this age group. Since these are usual procedures in clinical epidemiology research, the research team was trained to mitigate these potential limitations. Also, MINI has appropriate psychometric properties, however, there is some discussion in regard to the diagnostic criteria for mental disorders in the scientific community 25,26. Our research should be read in light of the current knowledge of the research field, in which diagnostic criteria for common mental disorders often overlap, and for that reason it is possible that comorbidities are, in fact, manifestations of the same condition.

It is important to call attention to some positive aspects of the present study, such as sample selection in which data was derived from a representative sample of young adults. The study of young adults allows early identification of the comorbidity cases profile allowing for the development of specific health policies with the goal of minimizing and preventing future impairment. 
We highlight that the present results can be generalized for the same age group to other similar communities. Also, the paper adds to the literature by studying in a population based study, not only one mental disorder at a time but by focusing on comorbidities between two highly prevalent groups of mental disorders. The study of comorbidities allows a broader perspective into mental disorders in a relatively young group, contributing considerably to prevention and mental health promotion.

\section{Conclusions}

These results draw attention to the association of social factors on cross diagnostic family comor- bidity on young adults. These findings enable a new perspective in regard to prevention and mental health promotion in Brazil. Social vulnerability (e.g. female gender; fewer years of education; low socioeconomic status; unemployment; and having divorced parents) is strongly related to comorbid mental disorders especially in this particular age group. Thus, early interventions are needed for young adults with primary disorders in order to avoid psychiatric comorbidities across the lifetime. Therefore, primary care professionals should be alert to psychosocial stress in this age group given its relationship with the early development of mental disorders. We suggest the implementation of prevention strategies in primary care focusing on the insertion of mental health professionals in basic health units.

\section{Resumen}

Esta investigación tuvo como objetivo evaluar la presencia de comorbilidad entre el estado de ánimo y la ansiedad, así como sus factores asociados en adultos jóvenes entre 18 y 24 años de edad, en Pelotas, sur de Brasil. Es un estudio poblacional transversal, basado en una selección de la muestra realizada por conglomerados. Se utilizó el Mini International Neuropsychiatric Interview (MINI) para evaluar los trastornos del estado de ánimo y la ansiedad. La prevalencia de los trastornos mentales en la muestra de estudio $(n=1.561)$ fue de 26,8\%, de los cuales 9,7\% tenían trastornos del estado de ánimo comórbidos y ansiedad. La comorbilidad entre el estado de ánimo y la ansiedad fue casi tres veces mayor entre las mujeres en comparación con los hombres $(p<0,001)$. Los niveles más bajos de educación, nivel socioeconómico $(p<0,001), y$ con padres divorciados $(p<0,050)$ se asociaron con trastornos del estado de ánimo comórbidos y ansiedad. La principal conclusión es que los factores sociales están altamente asociados con la comorbilidad entre el estado de ánimo y la ansiedad.

Trastonos Mentales; Salud Mental; Adulto Joven

\section{Contributors}

M. R. A. L. Molina contributed to the data analysis and interpretation, writing and approval of the final version. B. Spessato contributed to the data analysis and interpretation, critical review and approval of the final version. K. Jansen contributed to the study design, writing, data analysis, and approval of the final version. R. Pinheiro contributed to the study design and approval of the final version. R. Silva contributed to the study design, critical review, and approval of the final version. L. D. M. Souza contributed to the study design, data analysis and interpretation, writing, and approval of the final version.

\section{Acknowledgments}

Thanks to CNPq. 


\section{References}

1. Andrade LH, Wang Y-P, Andreoni S, Silveira CM, Alexandrino-Silva C, Siu ER, et al. Mental disorders in megacities: findings from the São Paulo Megacity Mental Health Survey, Brazil. PLoS One 2012; 7:e31879.

2. Bromet E, Andrade LH, Hwang I, Sampson NA, Alonso J, Girolamo G, et al. Cross-national epidemiology of DSM-IV major depressive episode. BMC Med 2011; 9:90.

3. Maragno L, Goldbaum M, Gianini RJ, Novaes HMD, César CLG. Prevalência de transtornos mentais comuns em populações atendidas pelo Programa Saúde da Família (QUALIS) no Município de São Paulo, Brasil. Cad Sáude Pública 2006; 22:1639-48.

4. Kessler RC, McGonagle KA, Zhao S, Nelson CB, Hughes M, Eshleman S, et al. Lifetime and 12-month prevalence of DSM-III-R psychiatric disorders in the United States. Results from the National Comorbidity Survey. Arch Gen Psychiatry 1994; 51:8-19.

5. Kessler RC, Chiu WT, Demler O, Merikangas KR, Walters EE. Prevalence, severity, and comorbidity of 12-month DSM-IV disorders in the National Comorbidity Survey Replication. Arch Gen Psychiatry 2005; 62:617-27.

6. De Graaf R, Bijl R, Smit F, Vollebergh W, Spijker J. Risk factors for 12-month comorbidity of mood, anxiety,and substance use disorders: findings from the Netherlands Mental Health Survey and Incidence Study. Am J Psychiatry 2002; 159:620-9.

7. Bilj RV, Ravelli A. Psychiatric morbidity, service use, and need for care in the general population: results of the Netherlands Mental Health Survey and Incidence Study. Am J Public Health 2000; 90:602-7.

8. Roy-Birne PP, Stang P, Witchen HU. Lifetime panicdepression comorbidity in the National Comorbidity Survey. Association with symptoms, impairment, course and help-seeking. Br J Psychiatry 2000; 176:229-35.

9. Andrews G, Slade T, Issakidis C. Deconstructing current comorbidity: data from the Australian National Survey of Mental Health and Well-Being. Br J Psychiatry 2002; 181:306-14.

10. Autonell J, Vila F, Pinto-Meza A, Vilagut G, Codony M, Almansa J, et al. Prevalencia-año de la comorbilidad de los trastornos mentales y factores de riesgo sociodemográficos asociados en la población general de España. Resultados del estudio ESEMeD-España. Actas Esp Psiquiatr 2007; 35:4-11.

11. Manso DS, Matos MG. Depressão, ansiedade e consumo de substâncias em adolescentes. Rev Bras Ter Cogn 2006; 2:73-84.

12. Meng X, D'Arcy C. Common and unique risk factors and comorbidity for 12-month mood and anxiety disorders among Canadians. Can J Psychiatry 2012; 57:479-87.

13. Lamers F, van Oppen P, Comijs HC, Smit JH, Spinhoven P, van Balkom AJ, et al. Comorbidity patterns of anxiety and depressive disorders in a large cohort study: the Netherlands Study of Depression and Anxiety (NESDA). J Clin Psychiatry 2011; 72:341-8.
14. Amorim P. Mini International Neuropsychiatric Interview (MINI): validação de entrevista breve para diagnóstico de transtornos mentais. Rev Bras Psiquiatr 2000; 22:106-15.

15. Victora CG, Huttly SR, Fuchs SC, Olinto MT. The role of conceptual frameworks in epidemiological analysis: a hierarchical approach. Int J Epidemiol 1997; 26:224-7.

16. Goldberg D, Huxley P. Common mental disorders: a bio-social model. London: Tavistock; 1992.

17. Jansen K, Mondin TC, Ores LC, Souza LDM, Konradt CE, Pinheiro RT, et al. Transtornos mentais comuns e qualidade de vida em jovens: uma amostra populacional de Pelotas, Rio Grande do Sul, Brasil. Cad Saúde Pública 2011; 27:440-8.

18. Hoffmann F, Petermann F, Glaeske G, Bachmann C. Prevalence and comorbidities of adolescent depression in Germany. An analysis of health insurance data. Z Kinder Jugendpsychiatr Psychother 2012; 40:399-404.

19. Jatobá DVN, Bastos O. Depressão e ansiedade em adolescentes de escolas públicas e privadas. J Bras Psiquiatr 2007; 56:171-9.

20. Tomcikova Z, Madarasova GA, Orosova O, van Dijk JP, Reijneveld AS. Parental divorce and adolescent drunkenness: role of socioeconomic position, psychological well-being an social support. Eur Addict Res 2009; 15:202-8.

21. Posada-Villa JA, Buitrago-Bonilla JP, Barreto YM, Ospina MR. Trastornos de ansiedad según distribución por edad, género, variaciones por regiones, edad de aparición, uso de servicios, estado civil y funcionamiento/discapacidad según el Estudio Nacional de Salud Mental-Colombia. NOVA Publ Cient 2006; 4:1-114.

22. Schraiber LB, D'Oliveira AFPL, Falcão MTC, Figueiredo WS, editors. Violência dói e não é direito: a violência contra a mulher, saúde e os direitos humanos. São Paulo: Editora UNESP; 2005.

23. Lima MCP, Menezes PR, Carandina L, Cesar CLG, Barros MBA, Goldbaum M. Transtornos mentais comuns e uso de psicofármacos: impacto das condições socioeconômicas. Rev Saúde Pública 2008; 42:717-23.

24. Justo LP, Calil HM. Depressão: o mesmo acometimento para homens e mulheres? Rev Psiquiatr Clín 2006; 33:74-9.

25. Nardi AE, Kapczinski F, Quevedo J, Hallak JEC, Freire R, Romano-Silva MA. The quest for better diagnosis: DSM-5 or RDoC? Rev Bras Psiquiatr 2013; 35:109-10

26. Insel T. National Institute of Mental Health: Director's blog. Transforming diagnosis. http://www. nimh.nih.gov/about/director/2013/transforming diagnosis.shtl/ (accessed on Apr/2014).

Submitted on $27 /$ Jan/2014

Final version resubmitted on 23/May/2014

Approved on 04/Jun/2014 